\title{
Pronunciation Problems among Palestinian English Major Students in Hebron University
}

https://doi.org/10.33806/ijaes2000.20.1.11

\author{
Mohammed Farrah \\ Nadia Halahlah \\ Hebron University, Palestine
}

\begin{abstract}
The purpose of this research is to identify few common pronunciation mistakes among Palestinian English major students in Hebron University and the factors that cause these problems. The paper discusses selected phonetic and phonological problems related to specific consonants and vowels besides problems related to pronunciation of consonant sequences. The participants of this study were 120 English major students from Hebron University. The researchers used a questionnaire and a recorded pronunciation test to collect the data. In addition to the previous instruments, interviews were conducted with eight students and two instructors. The findings of the study revealed that Hebron University English major students have difficulties in pronouncing English consonants

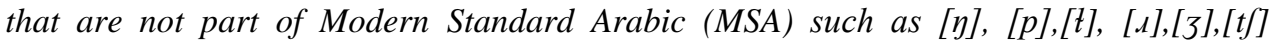

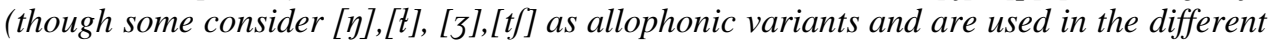
dialects of Arabic), problems in consonant clusters(epenthesis), silent letters, and vowels that have more than one pronunciation. During the interviews, the interviewees pointed various reasons for their errors and suggested some solutions to some of these pronunciation problems. Among the mispronunciation reasons mentioned are: interference from Arabic and the lack of correct models, exposure to native speakers, and practice. The researchers concluded that learners' errors are caused by several linguistic factors, such as the disparity between Arabic and English sound systems, the effect of spelling on pronunciation, the influence of the first language (L1) on the second language (L2), and English vowel inconsistency. Finally, ideas to overcome some of the pronunciation problems are suggested.
\end{abstract}

Keywords: Pronunciation Problems, interference, consonants, vowels, diphthongs

\section{Introduction}

Learners of any foreign language have to acquire pronunciation as one of the basic skills in order to communicate successfully in that foreign language. However, learning accurate pronunciation can be a problematic process because it necessitates learning how to articulate new unfamiliar sounds. Learners should be exposed to an intensive training for their organs of articulation in order to use the 
new places of articulation properly, namely when the mother tongue of the learner has a different system than that of the target language.

To speak language properly, it is necessary to comprehend its pronunciation as well. However, non-native English students face definite difficulties that inhibit them from attaining their goals in mastering the English language and the students of the English Department at Hebron University are not an exception. They face the same problems that other Arab students have. A number of previous studies (Ababneh 2018; Hassan 2014; Jabali, and Abuzaid, 2017; Kharma and Hajjaj 1989) reported that the speakers of a certain language have the same systematic problems in pronouncing the unfamiliar sounds of the new language.

Because there is a clear mismatch in the Arabic and English sound systems, English students at Hebron University face a number of difficulties in English pronunciation. One difficulty is found in some sounds that do not exist in the Arabic sound system such as the consonants /p/, / $\mathrm{t} / \mathrm{h} / \mathrm{z} /, / \mathrm{v} /$ (the sound $/ 3 /$ occurs in Arabic as an allophone of $/ \mathrm{d} /$ ). Some learners have the tendency to substitute these sounds with other sounds that are more familiar such as /b/, / /, /3/, /f/. Another difficulty appears in some similar, but not identical consonants in both English and Arabic. In these consonants there is a difference in the manner and the place of articulation. For example, the consonant / $t /$ in English is alveolar and it is aspirated in word initials if it is followed by a vowel like: time $\backslash$ taim $\backslash$, while in Arabic the sound /t/ is dental and it is not aspirated as in /ti:n/ (Abdelwahab 2015).

This study attempts to investigate the errors that English major students in Hebron University make while pronouncing specific English sounds and to suggest some solutions for better pronunciation.

\section{1 The Context of English Language Teaching in Palestine}

Following the Muslim Caliph Omar I (634-44) conquest of Jerusalem in the $7^{\text {th }}$ century, Classical Arabic of the Qur'an became the official language used in education in Palestine. During the Ottoman Empire rule of the region, the language of the government became Turkish. Turkish continued to have an official status that lasted until the end of World War I (Amara, 2003; Bianchi \& Abdel Razeq 2017).

From 1922 until 1948, Palestine came under the British occupation, and this established a linguistic link between the two countries and contributed to the rise of the English language in Palestine (Amara 2003; Bianchi \& Abdel Razeq 2017; Helm, Guth\& Farrah 2012).During the British occupation of Palestine, the English language became the main language of government besides Arabic, which was used by Palestinians (Amara 2018).

Due to the Israeli occupation of most of Palestine in 1948, the West Bank came under the rule of Jordan, and Gaza Strip under the rule of Egypt. Consequently, the West Bank and Gaza Strip were influenced by the language policy in these two countries. Both in Jordan and Egypt, English was taught as a foreign language and taught at schools from the Fifth Grade on ward (Bianchi \& Abdel Razeq2017). In 1967, Israel occupied the Gaza Strip, the West Bank and 
East Jerusalem. Interestingly, despite the Israeli occupation of these territories, the English language curricula from the Egyptian and Jordanian era remained intact. Accordingly, the West Bank schools had continued to use the same English curriculum used in Jordan ("New Living English for Jordan" NLEJ and "Progress in English Through Relevant Activities" PETRA Series.), and Gaza schools continued to use the Egyptian curriculum (Living English, Hello textbook series) until the gradual establishment of the Palestinian National Authority (PNA) first in Gaza and Jericho in 1994, major West Bank cities in 1995, and finally in Hebron in 1996 (Amara 2003).

With the establishment of the PNA, the General Administration of Curricula at the Ministry of Education had introduced its first English Language Curriculum for public schools from Grades1-12. Accordingly, English is introduced as a foreign language in Palestinian governmental schools from the age of six. The Series of the English textbooks is called "English for Palestine". The exposure of the students to English is limited to three to five lessons weekly. This means that students are not adequately exposed to English due to the limited number of English classes, and the lack of opportunities to use English outside classrooms (Salah \& Farrah 2012).

At university level, English Departments and Language Centres act as a support centre for students across universities. The English language is generally perceived as a means for international communication. So Palestinians have a positive attitude towards its instrumental value as it shows that they have been well-educated (Helm, Guth\& Farrah 2012).As shown in the academic plan (2017) at Hebron University, students should complete 127 credit hours. Students who like to join the English Department must get an average of 75+ in two university requirement courses (Reading and Writing in English \& Readings in English Literature), in order to be able to major in English. Also, there is only one oral course offered in the second year and only one course in phonetics is offered in the third year.

\subsection{Statement of the Problem}

Arab students, in general, face genuine problems in pronouncing English vowels and some consonants (Gilakjani and Ahmadi 2011). In spite of the explicit training they receive in English oral classes and their English phonetics and phonology courses, students continue to have poor pronunciation in English which results in communication problems. Learners get confused due to the various pronunciations of certain consonants and vowels. Therefore, much should to be done towards helping students particularly in linguistic areas related to phonetics and among other things. This research aims to be more innovative; in a sense, we will concentrate on the problems students have; then, we will move to teachers and discuss the problems that they have as students' performance is a reflection of their teachers' effort and linguistic abilities. Accordingly, the main aim of this paper is to examine these errors and to explore their causes. 


\subsection{Research Questions}

1. What are the common English pronunciation problems among English Major Students in Hebron University?

2. What are the plausible reasons behind making such errors in pronunciation?

3. What can be done to improve the English pronunciation level of the English Major Students in Hebron University?

\section{Literature Review}

Undoubtedly, pronunciation is an essential skill for mastering any foreign language, as communication depends on accurate pronunciation (Kharma and Hajjaj 1989).Pronunciation is described to be a complex aspect in learning a language. It is also a very delicate matter as mispronounced segments and suprasegments can cause listener disorientation and comprehension inhibition (Ababneh 2018; Hassan 2014).

Few researchers have concluded that such errors are caused by linguistic factors, Hassan (2014). On the other hand, other researchers like Levis and LeVelle (2012) have focused on the social effect on the pronunciation of nonnatives, while some other researchers such as Gilakjani and Ahmadi (2011) associated such errors with the learner himself and his personality and attitude.

Hassan (2014) mentioned certain linguistic factors that cause English mispronunciation by Sudanese students. These factors included: Mother tongue interference, sound system differences between LI and L2, inconsistency of English vowels influence of spelling on pronunciation. According to Hassan (2014), the mother tongue (L1) sometimes has an influence on the pronunciation of the second or foreign language (L2).

In order to illustrate the transfer from L1 to L2, Arab learners tend to replace the /p/ sound with /b/ because /p/ doesn't exist in Arabic; Arab students perceive both sounds as allophones of the same phoneme. They often mispronounce words such as 'Palestine', 'peace' and 'play' by replacing the /p/ with a /b/ (Jabali \&Abuzaid 2017 (Palestinian Arabic)). Many other studies have reported this common pronunciation problem for other Arab speakers (e.g. Ababneh 2018 (Saudi Arabic); Alkhuli, (1983) (Saudi Arabic); Hago\& Khan, (2015)(Saudi Arabic); Hassan, (2014) (Sudanese Arabic); Kharma, \&Hajjaj(1989)

Yule (1996) found that L1 influences the pronunciation of many sounds other than $/ \mathrm{p} /$ and $/ \mathrm{b} / \mathrm{such}$ as $/ \mathrm{t} /$ and $/ \mathrm{J} /, / \mathrm{z} /$ and $/ \mathrm{d} /$. That happens because L1 (in our case Arabic) establishes a certain sound system that makes its speakers pronounce the L2 sounds with an accent.

Carter and Nunan (2001) concluded that most of the pronunciation errors occur because of the L1 transfer. According to them, L1 speakers apply their language's phonological rules on L2 producing various pronunciation errors. Arabic has a single sound for each letter and there are no silent letters unlike English (Arabic has a one to one relationship between orthography and pronunciation).Arab students often get confused with English letters that can 
present more than one sound such as the letter (c) which can be pronounced as / $\mathrm{k} /$ or $/ \mathrm{s} /$, or they pronounce silent letters in an English word.

According to Hassan (2014), another linguistic factor that affects the pronunciation of EFL students is the sound system disparity between L1 and L2. According to Alkhuli (1983), native speakers of Arabic acquire the phonological system of their mother tongue which differs from the English system. Therefore, they tend to replace the foreign sounds with the closet sound in Arabic.

The Arabic sound system differs from the English one in the number of phonemes. According to Carter and Nunan (2001) due to the presence of differences in the sound system in the LI and L2, speakers may commit errors because they transfer their mother tongue sound system into the target language. Arabic has only twenty-eight phonemes (each letter represents one phoneme), in addition to three short vowels and two diphthongs while English has forty-four phoneme (twenty-four consonants and over twenty vowels (depending on the variety of English). According to O'Connor (2003), Arab students usually face problems in pronouncing the sounds that do not exist in their L1due to the remarkable differences between the English and Arabic vowel systems. That is why they may not achieve a native-like English pronunciation.

Although Modern Standard Arabic and English share many consonants $(/ \mathrm{d} /$, /b/, /t/, /j/, /f/, /z/, / /s/, /h//l//, /m/, /n/, /w/, /r/ and /y/), they are not necessarily identical (Abdelwahab 2015). For example, $/ t /$ is dental in Arabic while in English it is alveolar, /d/ is also dental in Arabic, but alveolar in English. The / $/ \mathrm{x} /$ is trilled in Arabic (Arabic / $\mathrm{s} /$ is a voiced tap (stop)), flat in British English and retroflexed in American English. With a trilled $/ r /$, the sound $/ r /$ is repeatedly produced, so the Arab speakers tend to produce these sounds according to the Arabic system places of articulation causing an Arabic accent (Alkhuli 1983).

However, there are consonants that exist exclusively in the English system such as $/ \mathrm{p} /, / \mathrm{g} /, / \mathrm{tg} /, / \mathrm{v} /, / \mathrm{g} /$ and $/ 3 /$, (Alkhuli 1983) and these are the sounds that Arab speakers have problems in producing (though $/ \mathrm{g} /, / \mathrm{t} / \mathrm{g}$ and $/ 3 /$ occur in many varieties of Arabic).The fourth linguistic factor is English vowel inconsistency (Hassan 2014). This means that one vowel letter in English can have more than one pronunciation, which results in confusion for the Arab learner. BaumanWaengler (2009) states that vowel errors are the most common among Arab learners because Arabic has only six monophthongs /a/, /i/, /u/, /a:/, /i:/, /u:/while English contains more than twenty vowels(depending of the variety of English). Gimson and Crittenden (1994) stated that speakers of languages that have simpler vowels than English (like Arabic) deal with English vowels as if they have just one pronunciation like their native language, and they pronounce them the same way they pronounce their language's vowels. In other words, the learner may change the quality or the quantity of some sounds (Hassan 2014). For example, most of the Arab students pronounce the words 'company' as /kompəni/ and 'among' as /əməy/ instead of /kımpəni/, /əmı /, respectively.

The last linguistic factor is the effect of spelling on pronunciation (Hassan 2014). It is known that English orthography does not represent its pronunciation (Yule, 1996). That is why Arab students make a lot of mistakes while reading a 
written text in English. A case in point is homographs such as the word 'lead' /li:d/ and 'lead'/led/.Another case is homophones such as the words 'sea' and 'see' and 'write' and 'right. 'Kharma and Hajjaj (1997: 14) point out that "the spelling of Arabic is overwhelmingly regular. In contrast, the spelling of English is seemingly very irregular."

In addition to the linguistic factors that may cause pronunciation problems are the social factors. For example, Levis and LeVelle (2012) emphasized that social factors play a significant role in pronunciation acquisition. They mentioned factors such as the learners' own views of their accents and their success in attaining accurate pronunciation. Some studies have highlighted the importance of social factors on the acquisition of L2 pronunciation. These include number of issues such as acculturation, discrimination for Munro (2003), and identity for Zuengler (1988).

Many previous studies have been concerned with teaching and learning pronunciation, identifying the most common pronunciation problems among students of various nationalities such as Korean, Spanish, French and Arab. These studies have tried to categorize pronunciation problems, to discover the reasons that hinder non-native students from pronouncing foreign sounds correctly, and to offer some recommendations on how to fix these problems among EFL students (Ababneh 2018; Altaha, 1995; Binturk, 2008; Hago and Khan 2015;Gilakjaniand Ahmadi 2011; Hassan 2014; Jabaliand Abuzaid2017; Kalaldeh 2016).

Altaha (1995) and Kharma and Hajjaj, (1989) concluded that the most problematic English consonant sounds among Arab EFL learners are /y/, /p/, / 1/, $/ \mathrm{I} /, / 3 /, / \mathrm{t} / /$ in addition to other errors such as replacing $/ \mathrm{v} /$ with $/ \mathrm{f} /$ and breaking consonant clusters (epenthesis).

Kalaldeh (2016) examined problems facing Jordanian students in English pronunciation in four aspects: consonants, consonant clusters, vowels and word stress. The sample of her study was limited to 10 male students. She chose the main challenging English consonants and vowels for Arabic speakers. The words chosen to represent the consonants and vowels were also checked for their frequency in English. The participants in her study read 158 words twice. The tested consonants are/p $-\mathrm{v}-\mathfrak{t}-\mathrm{d}-\mathrm{y}-\mathrm{J}-\mathrm{t} / .$. She found that Jordanian students often confuse the following phonemes $/ p-\mathrm{y}-\mathrm{I}-\mathrm{t} /$ with $/ \mathrm{b}-\mathrm{ng}-\mathrm{f}-1 /$ respectively. The author examined the following vowels: /I - $\varepsilon-\mathrm{a}-\rho$ : - o $-\partial /$.She found that the participants regularly confused the vowels in words like "sit, set" and the vowels/diphthongs in words like "thought, goat" where the participants merged a single vowel to exemplify both distinctions as [e] and [o:], respectively.

Tushyeh, (1996) conducted a study to examine the problems facing Palestinian EFL students. He found that they have problems in the realization of sounds which do not exist in their L1. Likewise, Jabali and Abuzaid (2017) conducted a study to identify the English consonant sounds that were mispronounced. They found that the most common mispronunciations appear for the sounds $/ \mathrm{p} /, / \mathrm{t} \mathrm{f} /, / \mathrm{d} 3 /, / \mathrm{I} /$ and $/ \mathrm{y} /$ respectively. Unfortunately, their study did not include sixth sound mentioned above / $\mathrm{t} /$ in their test. 
Finally, Shamallakh (2018) conducted a study to examine problems facing EFL students in pronouncing English vowels. The sample of his study was limited to 71 male university students at the Islamic University-Gaza (IUG). The researcher used two tools to achieve the goals of the study. First, he used a questionnaire to examine students' attitude towards pronouncing English vowels. Second, he used interviews that included a word list (test) to be pronounced by the interviewed students. The test involved 12 monophthongs and 8 diphthongs. $\mathrm{He}$ found that the most problematic monophthong sounds are: /æ/, /p/, / :/, /u:/, /3:/ and /i:/.Moreover, the most problematic diphthong sounds are: $v ə /$, /Іə/, /əv/, /eə/, /eI/ and /av/. Based on the finding of the research, he recommended paying attention to speaking skills including pronunciation.

Several studies have suggested a number of methods to overcome pronunciation problems (Gilakjani and Ahmadi 2011; Kharma and Hajjaj 1989; Munro, 2003). For example, Gilakjani and Ahmadi (2011) suggested that teachers can adopt certain methods to improve their students' pronunciation such as listening to authentic conversations and maintaining conversations with native speakers. They also suggested the use of the minimal pairs drills for the problematic sounds.

\section{Method}

\subsection{Design of the study}

This study used several methods to collect data using quantitative and qualitative approaches. The quantitative data was collected through a questionnaire and a recorded test. In order to validate the findings, the researchers used a triangulation technique to compare the data obtained from the questionnaire and the test. The qualitative data was collected through interviews with students and instructors.

\subsection{Participants}

The participants of the questionnaire were 100 third and fourth year English major students in Hebron University. They were 21 males and 78 females. They were enrolled in the second semester of the year 2017-2018.

The Participants of the recorded test were twenty English major students in Hebron University. They were sixteen females and four males selected randomly from the third and fourth year students. They have never been to an English speaking country nor did they have any previous exposure and communication with native speakers of English. The participants' academic levels vary, and their GPAs range from $70 \%-90 \% .10$ of them took the phonetic course in the previous semester, and the rest took it at the time of the research (second semester of the academic year 2017-2018).

\subsection{Data Collection}

In order to achieve the objectives of the study, three research instruments were used to collect data: a questionnaire, recorded pronunciation test and interviews with students and instructors. The questionnaire was used to find out the most common English pronunciation errors from the participants' point of view. The 
test was done to confirm the findings of the questionnaire, and to discover other errors that might not have been mentioned in the questionnaire.

\subsection{The Development and Distribution of the Questionnaire}

The questionnaire here is developed in line with that used by Hassan (2014) and has 23 items. It consists of two parts. The first part involves the participant's personal data (Gender, Major, Academic Level and GPA). The second concerns the most common problematic sounds in English for Arab speakers and the suggested methods used to improve the student's pronunciation of English. The questionnaire used the Likert scale to indicate the degree of agreement and disagreement from 1-5 which were: strongly disagree, disagree, neutral, agree and strongly agree, respectively. A hundred questionnaires were filled. Quantitative data was analyzed statistically using SPSS version 22.The questionnaire reliability was examined and the result showed that the overall Cronbach Alpha Coefficient of the questionnaire was $(\mathrm{r}=.85)$, indicating a very good degree of internal consistency. This means that the questionnaire was a reliable instrument.

\subsection{The Pronunciation Test}

The researchers designed a pronunciation test in order to compare the students' opinions given in the questionnaire and the real pronunciation of the students.

The test consisted of familiar words to be read by the participants to discover the frequency of errors among them. The readings were recorded using a laptop and a headset with a microphone.

The test was conducted in a quiet room in the Resources Center in the Activities Building at Hebron University. Before starting the test, the students were informed of the purpose of the research, and they were told that their pronunciation will be recorded. The students were given a list of words, and they had three minutes to prepare. Quantitative data was analyzed statistically using SPSS version 22 .

\section{Results}

\subsection{The Questionnaire}

This section contains the results obtained from the analysis of the students 'answers for the questionnaire. The first section presents the participants' demographic data. The second section reports on the 23 items of the questionnaire.

Table 1 summarizes information for 100 participants (gender, academic level, major, and GPA).

Table 1: Participants' information

\begin{tabular}{|l|l|l|l|l|}
\hline es & Variabl & Frequen & Percent & $\begin{array}{l}\text { Cumulative } \\
\text { Percentage }\end{array}$ \\
\hline
\end{tabular}




\begin{tabular}{|c|c|c|c|c|c|}
\hline \multirow[t]{4}{*}{ Gender } & Male & & 21 & 21 & \multirow[t]{4}{*}{100} \\
\hline & Female & & 78 & 78 & \\
\hline & Missing & & 1 & 1 & \\
\hline & Total & $\begin{array}{ll} & 1 \\
0 & \end{array}$ & 10 & 100 & \\
\hline \multirow[t]{3}{*}{ Year } & Third Year & & 50 & 50 & \multirow[t]{3}{*}{100} \\
\hline & Fourth Year & & 50 & 50 & \\
\hline & Total & 0 & 10 & 100 & \\
\hline \multirow[t]{5}{*}{ Major } & $\begin{array}{l}\text { English } \\
\text { Literature }\end{array}$ & & 29 & 29 & \multirow[t]{5}{*}{100} \\
\hline & $\begin{array}{l}\text { Minor } \\
\text { French }\end{array}$ & & 30 & 30 & \\
\hline & $\begin{array}{l}\text { English } \\
\text { Methods }\end{array}$ & & 37 & 37 & \\
\hline & Missing & & 4 & 4 & \\
\hline & Total & 0 & 10 & 100 & \\
\hline \multirow[t]{4}{*}{ GPA } & $65-74$ & & 21 & 21 & \multirow[t]{4}{*}{100} \\
\hline & $75-84$ & & 55 & 55 & \\
\hline & $\begin{array}{l}85 \\
\text { above }\end{array}$ & & 24 & 24 & \\
\hline & Total & 0 & 10 & 100 & \\
\hline
\end{tabular}

Table 1 indicates that most of the respondents were females, and this reflects the general population of Hebron University. The majority of the participants were $78(78 \%)$ females while 21 were males. As for the academic level, $50 \%$ were juniors and $50 \%$ seniors. Regarding the participants' majors, the majority were English Methods students (37\%). Minor French students constitute $30 \%$ of the total number of the participants while English Literature students 
constitute 29\%. Regarding their Grade Point Average (GPA), 55\% of the students have an average ranging between $75-84,24 \%$ have 85 and above, and $21 \%$ have an average ranging between 65-74.

Descriptive statistics were calculated for all the questionnaire items to examine the attitudes of the English department students towards the most common errors in English pronunciation.

Table 2: Descriptive statistics (Means and Standard Deviations) for the different errors, methods and solutions of improving English pronunciation.

\begin{tabular}{|c|c|c|c|c|}
\hline $\begin{array}{l}\text { Item } \\
\text { No. }\end{array}$ & Item & No & Mean & SD \\
\hline 23 & $\begin{array}{l}\text { Listening to the English sounds and words } \\
\text { through technology and audio aids (tape, CD, } \\
\text { TV channels) help improve students' } \\
\text { pronunciation. }\end{array}$ & 100 & 4.120 & .99778 \\
\hline 1 & $\begin{array}{l}\text { Most of the students pronounce /b/ instead of } \\
\text { /p/ in words like "pen", "map", "happy". }\end{array}$ & 100 & 3.880 & 1.1035 \\
\hline 22 & $\begin{array}{l}\text { Native English teachers can improve the level } \\
\text { of pronunciation in the English Department. }\end{array}$ & 100 & 3.850 & 1.0766 \\
\hline 5 & $\begin{array}{l}\text { Many students pronounce the } / \mathrm{r} / \text { as a trill } \\
\text { instead of a retroflex } / \mathrm{d} / \text { in "burn" and "here". }\end{array}$ & 100 & 3.810 & .91778 \\
\hline 21 & $\begin{array}{l}\text { Looking up words in the dictionary helps } \\
\text { students improve their English pronunciation. }\end{array}$ & 100 & 3.720 & 1.07384 \\
\hline 13 & $\begin{array}{l}\text { Many students pronounce diphthongs as a } \\
\text { single sound in "no" and "go". }\end{array}$ & 100 & 3.710 & 1.1746 \\
\hline 10 & $\begin{array}{l}\text { Many students pronounce the vowel in "moth" } \\
\text { as } / \mho / \text { instead of } / \mathrm{b} / \text {. }\end{array}$ & 100 & 3.710 & .93523 \\
\hline 20 & $\begin{array}{l}\text { Students mispronounce some sounds as they } \\
\text { predict the pronunciation from the spelling. }\end{array}$ & 100 & 3.710 & .89098 \\
\hline 11 & $\begin{array}{l}\text { Many students pronounce the vowel in } \\
\text { "constraint" as } / \mathrm{o} / \text { instead of } / \mathrm{\partial} / \text {. }\end{array}$ & 100 & 3.700 & 1.1146 \\
\hline 3 & $\begin{array}{l}\text { Many students pronounce } / \mathrm{ng} / \text { instead of the } \\
\text { nazal } / \mathrm{y} / \text { in "sing". }\end{array}$ & 100 & 3.690 & 1.1780 \\
\hline 12 & $\begin{array}{l}\text { Many students pronounce 'tomb' as } / \mathrm{u} / \text { instead } \\
\text { of } / \mathrm{u} / \mathrm{\text {. }}\end{array}$ & 100 & 3.680 & 1.1090 \\
\hline 17 & $\begin{array}{l}\text { Many students may insert vowels between the } \\
\text { consonants; 'asked'is pronounced /askid/ } \\
\text { instead of /askt/. }\end{array}$ & 100 & 3.670 & .87681 \\
\hline 4 & $\begin{array}{l}\text { Many students do notdistinguish between dark } \\
\mathrm{L} / \mathrm{t} / \text { and light } \mathrm{L} / \mathrm{l} / \text { in "file" and "little". }\end{array}$ & 100 & 3.660 & 1.1999 \\
\hline 14 & Many students pronounce the silent letters in & 100 & 3.570 & 1.1122 \\
\hline
\end{tabular}


words such as 'debt', 'doubt' and 'aisle'

6 Students tend to pronounce the sound /3/ with $/ \mathrm{dz} /$ as in the words "garage" and "measure".

100

$3.520 \quad 1.1934$

16 Many students find it difficult to distinguish the two vowel sounds of "sit" and "set'.

100

$3.510 \quad 1.0834$

9 Many students pronounce the vowel in "bay" as /ai/ instead of /eI/.

100

$3.350 \quad .95743$

8 Students tend to pronounce /s/ instead of /z/ in 100 "hose" and /z/ instead of /s/ in "gas"

$3.350 \quad 1.2902$

2 Many students pronounce $/ \mathrm{J} /$ instead of $/ \mathrm{t} / \mathrm{in}$

100 words such as "much", "furniture".

$3.290 \quad .98775$

100 "choose" "chapter", and "chew".

18 Many students pronounce the /v/ sound as /f/ in "of".

100

$3.230 \quad 1.2542$

15 Many students pronounce the $/ \mathrm{k} /$ sound as /s/ in words like "concrete".

100

$3.170 \quad 1.2394$

19 Many students pronounce /f/ instead of /v/ in words like "oven".

100

The 23 items are divided into common pronunciation problems and suggested methods to avoid such problems. The results of each will be presented separately. Regarding the most common pronunciation errors, most of the English students of Hebron University agree that more often than not, they confuse $/ \mathrm{p} /$ with /b/ in words such as "happy", "map" and "pen". Item number 1 which investigates this error scored the highest agreement among other items concerning problematic sounds. This result is in line with the findings of Hago and Khan (2015).

The second most common pronunciation error according to the English Department students is the incorrect production of the / $\mathrm{x} /$ approximant of English (item 5). Students agree that most of them pronounce the $/ \mathrm{r} / \mathrm{as}$ it is in the Arabic system (trilled) instead of the English / $\mathbf{d} /$ (retroflex).

Item number 13 scored a very close agreement to the previous items. Students tend to agree that diphthongs can cause pronunciation problems in words such "go" and "no" (In English these words can be pronounced both as a diphthong or a monophthong (both pronunciations are correct)). They agree that 
they pronounce diphthongs as single vowels in such words so that they become /go/ and /no/ instead of /nəひ/ and /gəo/. Arabic system contains very few diphthongs. That is why students cannot distinguish them.

Items number 10, 11, 12 concerning vowel errors scored a high agreement level as well. Students agree that they have difficulties in distinguishing different vowel sounds because of two main reasons which are the English vowel inconsistent match between orthography and pronunciation as indicated in item 20 which scored a high agreement. The inconsistent match between orthography and pronunciation was also reported by Yule (1996).

As for the nasal sound $/ \mathrm{y} /$, students believe that it can be a problematic sound as indicated by the high overall mean for this item. This goes in line with Jabali and Abuzaid (2017) who conducted a study at An-Najah National University, Palestine. They found out that students either use the sounds $/ \mathrm{n}+\mathrm{g} /$ or $/ \mathrm{y}+\mathrm{g} /$ instead of $/ \mathrm{y} /$, and that only $10 \%$ of the students pronounced the sound correctly.

Regarding the consonant clusters, item 17 got a high agreement which means that students agree that they tend to insert vowels between consonants (usually /ə/) (this is called linguistically 'epenthesis') in words like "asked". Hago and Khan, (2015) reported that this is a very common phenomenon among Saudi learners who tend to break up consonant clusters as well.

Item 4 achieved a good agreement which means that some students cannot correctly produce the dark $\mathrm{L} / \mathrm{t} /$, so they produced the clear $\mathrm{L} / \mathrm{l} / \mathrm{in}$ all positions. This is similar to what Hassan, (2014) discovered among Sudanese students.

Item 14 also achieved a good agreement which indicates that some students pronounce silent letters in "debt", "doubt" and "aisle". This is in line with Ababneh, (2018) who concluded that Saudi learners have the same problem.

Items number 6, 8, 16, 2, 7, and 9recorded agreement to a lesser extent than the above mentioned ones. That means that some of the students agree that some of them tend to replace the sound $/ 3 /$ with $/ \mathrm{d} 3 /$ as in the words "garage" and "measure", replace /z/ with /s/ in "hose", /s/ with /z/ in "gas", / t f/ with /f/ in "chapter" and "furniture". Moreover, as item 16 reveals some of them tend to agree that many students find it difficult to distinguish vowels in "sit" and "set".

The least agreed on items were $18,15,19$. That means that some of the students disagree that most of them tend to replace /v/ with /f/ in "of". Also it seems that most of them do not tend to replace the $/ \mathrm{k} /$ sound with $/ \mathrm{s} /$ in "concrete", and /v/ with /f/ in "oven". Many of them also claim that they pronounce the vowel in "bay" correctly as /er/.

According to the questionnaire, errors which are in specific sounds can be ordered from most to least frequent as the following: replacing $/ \mathrm{p} /$ with $/ \mathrm{b} /$, replacing $/ \mathrm{d} /$ with $/ \mathrm{r} /$, pronouncing diphthongs as a single vowel, mispronouncing vowels, replacing $/ \mathrm{y} / \mathrm{with} / \mathrm{n}+\mathrm{g} /$, breaking up consonant clusters ('epenthesis'), pronouncing clear $\mathrm{L} / \mathrm{l} / \mathrm{in}$ all positions, pronouncing silent letters, replacing $/ 3 /$ with $/ \mathrm{d} 3 /$, replacing / $\mathrm{t} / \mathrm{with} / \mathrm{f} /$, replacing $/ \mathrm{f} /$ with $/ \mathrm{v} /$, replacing $/ \mathrm{k} / \mathrm{with} / \mathrm{s} /$, and finally replacing $/ \mathrm{v} /$ with /f/. 
Tushyeh (1996), Altaha (1995), Avery and Ehrlich (1992) and Kharma and Hajjaj (1989) conducted studies that found that the most common errors among Arab English learners are $/ \mathrm{y} /, / \mathrm{p} /, / \mathrm{t} /, / \mathrm{l} /, / \mathrm{Z} /, / \mathrm{t} /$ with different percentages from this study. However; they also found that students confuse /v/ with /f/ as in pronouncing 'very' with an /f/.However, as revealed from the questionnaire, such a problem was not found to be very common for the students of Hebron University. So, it can be concluded that the Arab speakers errors vary according to their dialects.

The second domain that was investigated by the questionnaire was the methods and techniques that can be used to develop pronunciation. The most agreed on item in the whole questionnaire was 23 which means that the majority of students believe that the most effective method to improve pronunciation skills is listening to the English sounds and words through technological devices and audio aids. The second method that got a high agreement was that having native English teachers can improve the level of pronunciation in the English Department. They also agree that looking up words in the dictionary helps students improve their English pronunciation.

\subsection{The Pronunciation Test}

According to the test, it has been observed that there is a disparity in the percentages of mispronunciation of consonants and vowels sounds among the 20 students who participated in the pronunciation test. The most common errors appear in Tables 3, 4 and 5, where $\mathrm{TS}=$ target sound, $\mathrm{NS}=$ number of students, NSI= number / percentage of students who pronounced the word incorrectly.

Table 3 presents the most frequent consonant errors.

Table 3:Most frequent consonant errors

\begin{tabular}{|c|c|c|c|c|}
\hline Words & $\begin{array}{ll} & \mathrm{T} \\
\mathrm{S} & \end{array}$ & S & NSI & $(\%) \quad$ NSI \\
\hline Gas & $/ \mathrm{s} /$ & 20 & 17 & 85 \\
\hline Sing & $/ \mathrm{y} /$ & 20 & 16 & 80 \\
\hline Of & $/ \mathrm{v} /$ & 20 & 15 & 75 \\
\hline File, little & $/ \mathrm{t} /$ & 20 & 15 & 75 \\
\hline Happy, Pin & $/ \mathrm{p} /$ & 20 & 14 & 70 \\
\hline Here, burn & $/ \mathrm{d} /$ & 20 & 14 & 70 \\
\hline
\end{tabular}




\begin{tabular}{|l|l|l|l|l|}
\hline Hose & $/ \mathrm{z} /$ & 20 & 13 & 65 \\
\hline Garage & $/ 3 /$ & 20 & 12 & 60 \\
\hline Chapter & $/ \mathrm{t} / /$ & 20 & 10 & 50 \\
\hline Furniture & $/ \mathrm{t} /$ & 20 & 9 & 45 \\
\hline Measure & $/ 3 /$ & 20 & 9 & 45 \\
\hline Choose & $/ \mathrm{t} /$ & 20 & 7 & 35 \\
\hline Oven & $/ \mathrm{v} /$ & 20 & 6 & 20 \\
\hline Southern & $/$ / $/$ & 20 & 5 & 15 \\
\hline Off & $/ \mathrm{f} /$ & 20 & 0 & 0 \\
\hline
\end{tabular}

Table 3 indicates that the most frequent error is replacing the sound /s/ in the word 'gas' with the sound /z/. Yet it cannot be considered as a general error, for this error is specific to these words only and may not apply to other words.

The second error appears to be pronouncing the velar nasal [ $\mathrm{y}]$ when it appears in ing-endings, which were produced as two sounds: $[\mathrm{n}]+[\mathrm{g}]$. For example, the word 'sing' was pronounced as /sing/, instead of as a velar nasal /sin.

$75 \%$ of the students produced the word 'of' as /əf/ and not /ov/. This finding contradicts somehow the results of the questionnaire as mentioned above.

$75 \%$ of the students had a problem in pronouncing the dark L/t/. They produced the clear $\mathrm{L} / \mathrm{l} / \mathrm{in}$ all positions. / $/ \mathrm{t} / \mathrm{is}$ velarized, where the back of the tongue is raised against the velum, while /l/ is not velarized. English speakers produce / $\mathrm{A} /$ after the vowel sounds in a syllable. Arab speakers have a problem producing this heavy unfamiliar sound since it is always clear and non-velarized in Arabic, except in the word 'Allaah'.

The $/ \mathrm{p} /$ was mispronounced by $70 \%$ of the students and replaced with $/ \mathrm{b} /$. Most of them read the words "happy, pin" as /habi/ and /bin/. Another problematic consonant for the students was the $/ \mathrm{x} / \mathrm{sound}$. $70 \%$ of the students pronounced it as the Arabic tap sound $/ \mathrm{s} /$. Therefore, the word 'burn' was produced as $/$ bern/ instead of $/ \mathrm{b} 3 \mathrm{n} / \mathrm{n}$ or $/ \mathrm{b} 3 . \mathrm{m} /$.The $/ \mathrm{r} /$ sound is different in Arabic and English. Arabic[r] is an alveolar trill, so it is rolled or trilled and the tip of the tongue touches the alveolar ridge to produce it unlike the English $[\mathrm{I}]$ which is smoother (frictionless retroflex continuant), and the tongue lies hanging in the oral cavity 
and does not touch the alveolar ridge.

$65 \%$ of the students produced a /s/ in 'hose 'instead of a / $/$. This error is more frequent than predicted. The test results also reveal that the sound /3/ was replaced with /dz/ in the words"'garage" (60\%) and "measure" (45\%).

Replacing $/ \mathrm{t} /$ / with $/ \mathrm{J} /$ was also a common problem. For instance, $50 \%$ of the subjects replaced $/ \mathrm{t} / /$ with $/ \mathrm{J} /$ in the word 'chapter'. However, the percentage declines in the pronunciation of "furniture" (45\%) and "choose" (35\%). This finding needs further investigation to arrive to a better explanation for this result.

The least common errors were mispronouncing /v/ in "oven" as /f/ (20\%) and replacing /ð/ in 'southern' with $/ \theta /$.None of the students replaced /f/ with $/ \mathrm{v} /$ in 'off'. Table 4 presents students' pronunciation of silent letters.

Table 4: Students' pronunciation of silent letters

\begin{tabular}{|l|l|l|l|l|}
\hline Words & TS & NS & NSI & NSI (\%) \\
\hline Debt & Silent "b" & 20 & 13 & 65 \\
\hline Isle & Silent "s" & 20 & 5 & 25 \\
\hline Doubt & Silent "b" & 20 & 4 & 20 \\
\hline
\end{tabular}

Table 4 reveals the students' errors regarding the pronunciation of silent letters. In the questionnaire, item 14 scored good agreement indicating that some students pronounce silent letters in "debt", "doubt" and "aisle". However, the pronunciation test results indicate that the pronunciation of the silent letters percentage varies from one word to another. $65 \%$ of the students pronounced $/ \mathrm{b} /$ in 'debt'. The percentage declines in the words "Isle" and "doubt" to reach $25 \%$ and $20 \%$, respectively. Clearly, the familiarity of the word plays a major role in pronouncing it correctly. Apparently, the words "doubt" and "isle" are more common to students than "debt".

Regarding the consonant clusters (epenthesis), the test results revealed that a considerable number of the students (60\%) pronounced "asked" as /askid/ instead of /askt/. This could mean that students of Hebron University face a problem in pronouncing the consonant clusters. However, there is a need for more than one word to test consonant cluster pronunciation to arrive to a valid conclusion. Table 5 presents students' pronunciation of vowels.

Table 5: Student's pronunciation of vowels

\begin{tabular}{|l|l|l|l|l|}
\hline Words & TS & NS & NSI & NSI (\%) \\
\hline Constraint & $/ 2 /$ & 20 & 18 & 90 \\
\hline
\end{tabular}




\begin{tabular}{|l|l|l|l|l|}
\hline Tomb & /u:/ & 20 & 18 & 90 \\
\hline No, Go & /əo/ & 20 & 16 & 80 \\
\hline Set & /e/ & 20 & 14 & 70 \\
\hline Bay & /eI/ & 20 & 13 & 65 \\
\hline Moth & $/ \mathrm{p} /$ & 20 & 13 & 65 \\
\hline Sit & /I/ & 20 & 2 & 10 \\
\hline
\end{tabular}

Table 5 presents the most common vowel errors among the English Department students. The results indicate that the vowels have the highest percentages amongst all errors types. This means that the largest number of the students have more ofa problem in pronouncing vowels than consonants. It appears that the most problematic vowel for the students is the schwa / $/$ /, for $90 \%$ of the students pronounced the word "constraint" as/kon'streint/ instead of /kən'streInt/.

It also appears that students fail to distinguish the variations of English vowels, for $90 \%$ of the students pronounced 'tomb' as /tomb/ instead of /tu:m/ and $80 \%$ of the students failed to distinguish the diphthongs in "no,go". They were pronounced by the students as $/ \mathrm{no} /, / \mathrm{go} /$, but the natives pronounce them /nəo/ and /gəo/.

The diphthong /eI/ in 'bay' was replaced with /ar/ in $65 \%$ of the cases. Similarly, the vowel / $\mathrm{p} /$ in 'moth' was mispronounced as $/ \mho /$.

Additionally, students seem to fail to differentiate between the vowels in the words 'set' and 'sit'. $70 \%$ of the participants pronounced the vowel in 'set' as $/ \mathrm{I} /$ while only $10 \%$ pronounced the vowel in 'sit' as /e/. This means that students tend to pronounce the two words with the same vowel $/ \mathrm{I} /$.

\subsection{Results of the interviews:}

The researchers interviewed eight students and two instructors. They were asked the following questions:

\section{What are the plausible reasons behind making such errors in pronunciation?}

The interviewees identified the following reasons behind committing errors in pronunciation.

\section{A. Lack of adequate preparation in pronunciation at schools.}

Most of the students reported that they were not exposed to sufficient instruction or exercises on how to pronounce English sounds at schools. They explained that the books did not have adequate pronunciation drills and activities to learn 
pronunciation properly. Moreover, they added that though the new Palestinian curriculum aims to enhance students' pronunciation, little progress is shown on the part of the learners as they are inadequately exposed to pronunciation activities and practice inside the classroom.

\section{B. The offered pronunciation courses at University do not fully qualify teachers to teach pronunciation.}

All the students and the instructors raised the issue that there are not sufficient courses to teach pronunciation and the offered pronunciation courses do not fully qualify teachers to teach pronunciation. Most of the interviewees mentioned that only the phonetic course that is offered in the third year qualifies teachers to teach pronunciation. One student clarified that "there are no direct instructions on how to teach students pronunciation or even speaking." Another student added "The offered courses are not sufficient because they do not teach the students pedagogically; they do not qualify teachers to teach. For example, they emphasize theory over practice".

\section{Some teachers neglect teaching pronunciation}

Some interviewees raised the issue that some students do not know how to pronounce English sounds accurately because of the interference between the sounds of their mother tongue and the foreign language sounds or because they never heard the sounds from native speakers. They emphasized that teaching pronunciation needs preparation and as one of them said "Unfortunately, not all teachers prepare for pronunciation; as a result, we notice variety in pronunciation." Another student suggested that teachers vary in their levels of L2 acquisition, so definitely they will differ in their competence levels which will later affect their teaching practices.

\section{What are the most problematic English sounds? and why?}

When the interviewees were asked about the most problematic English sounds, they mentioned vowels diphthongs, schwa and certain consonants. Most of them reported L1 interference and differences from L2 sounds system as major reasons behind this problem. They believe that students commit errors in pronouncing these sounds because some of them do not exist in Arabic or due to the lack consistency in their orthographic transcript. This influences students' ability to articulate them. Regarding vowels, one teacher mentioned that certain words have different vowel sounds 'good', 'food' and 'blood' (/ / /, /u:/ and $/ \Lambda /)$. Other interviewees mentioned problems with diphthongs and the schwa. One interviewee explained "students have difficulties in pronouncing these sounds because they are unaware of them and they do not have them in Arabic". 
Similarly, the interviewees mentioned that learners of English face difficulties in the pronunciation some consonants because they do not exist in Arabic. One teacher clarified "some students have problems in pronouncing some English sounds like: $/ \mathrm{y} /, / \mathrm{p} /, / \mathrm{t} /, / \mathrm{d} /, / 3 /$ and $/ \mathrm{t} / \mathrm{l}$." This is in agreement with several studies. For example, Kalaldeh (2016,: 400) reported that Arab learners produce $/ \mathrm{y} /$ with a following voiced velar stop $/ \mathrm{g} /$ because "the velar nasal $/ \mathrm{y} /$ does not exist in Arabic as a phoneme, but as an allophone of $/ \mathrm{n} /$ and is always produced in the context $/ \mathrm{nk} / \mathrm{or} / \mathrm{ng} /$ '. These sounds require specific movement of the lips or and the tongue which Arab students are not used to. So, they prefer pronouncing a similar sound which they are familiar with.

Another problem was the articulation of the post-alveolar affricate $/ \mathrm{t} / \mathrm{and}$ substituting it with the post-alveolar fricative counterpart $/ \mathrm{g} /$. The first consonant $/ \mathrm{t} /$ of the affricate $/ \mathrm{t} / \mathrm{w}$ was deleted. Another interviewee mentioned the surrounding context and part of speech as a factor in pronouncing certain English consonants (Bath, Breath vs. bathe breathe). She added that the manner of articulating /l/, / / / depends on the surrounding phonemic context. Other interviewees mentioned that some Arab learners tend to break English consonant clusters by adding short vowels because Arabic does not have consonant clusters in words like spring, abstract and against. They add short vowels between the letters. Some interviewees explained that the reason behind committing pronunciation errors is interference from Arabic. Other interviewees mentioned the lack of correct models, exposure to native speakers, and practice as some reasons for pronunciation errors.

\section{How do you motivate students to improve their pronunciation?}

To answer this question, the interviewees mentioned a number of suggestions for motivating students to improve their pronunciation. The following are some of tips that they suggested:

- Using information, communication technologies (ICTs) in the classroom. This includes watching movies and videos and listening to songs.

- Exposing students to authentic language and practicing it. For example, they suggested asking students to watch videos that show them how native speakers pronounce English sounds (vowels, diphthongs, syllables, stress and rhyme) and repeat after the native speakers.

- Making learning fun by encouraging students to read the words by playing games, role-play, and practicing the sounds individually and in groups. Games and role plays give the students the chance to utter and pronounce the sounds loudly.

- Using some audio tracks for certain sentences in the textbook to show the correct pronunciation and to focus on stress and rhyme. Also, I read a word 
or a sentence aloud from the textbook by showing the stress and rhyme of the word.

- Designing resources and materials to teach our students certain pronunciation rules.

- More courses should be given on how to teach the English pronunciation for children due to the differences in pronouncing sounds between Arabic and English.

- Delete

\section{Discussion}

English major students in Hebron University have a considerable number of pronunciation errors that affect their learning process and speaking skills. Students have a general tendency to replace /p/ with /b/, / y/ with /n/+/g/, / $/$ with /1/, / / / with /d/, /3/ with /dz/, /t $/ /$ with / //, /s/ with /z/ or vice versa, and /ð/ with $/ \theta /$. Moreover, students have other errors such as pronouncing silent letters, epenthesis in consonant clusters, and mispronouncing certain vowels.

The results of this study are in line with similar previous studies. Students did not make errors in sounds that exist in the Arabic sound systemTushyeh (1996).

This study also came up with a result that the participants' main errors were replacing the sounds that are not found in Arabic with similar counterparts like the case of replacing /p/ with $/ \mathrm{b} /$.

Hago and Khan (2015) found that the most problematic consonant sound for Arab speakers in English is /p/. Jabali and Abu Zaid, (2017) also found that the most frequent error among English consonants is /p/. However; in this study it is obvious that the students strongly agree that they commit the same error frequently, yet the test shows that it is the second most frequent error after the $/ \mathrm{y} /$ sound. Hago and Khan (2015) also found that $/ \mathrm{y} /$ sound is problematic for the Saudi learners as well.

Tushyeh (1996), Altaha (1995), Avery and Ehrlich (1992) and Kharma and Hajjaj (1989) conducted studies that found that the most common errors among Arab English learners are $/ \mathrm{y} /, / \mathrm{p} /, / \mathrm{t} /, / \mathrm{x} /, / \mathrm{z} /, / \mathrm{t} / /$ with different percentages from this study. However, they also found that students make an error in pronouncing the sound /v/ and that they replace it with /f/. For example, "very"is mostly pronounced as/feri/, but this study suggests that the students of Hebron University do not commit such an error as frequent $(20 \%)$ in the word "oven".

As for the pronunciation of silent letters, this error can be attributed to the effect of spelling on pronunciation. Yule (1996) explains that the English orthography affects the EFL students' pronunciation, especially Arab students. Silent letters are not common in Arabic, except for the case of the grammar rule of ĀalHurfulAlQamria (Moon letters) - ĀalĀaHrufššamsiyyat (Sun letters), while in English silent letters are frequent. It is noticed that the number of students who pronounce silent letters varies individually. This could be an effect of their GPA 
or academic level. It is noticed here that students with higher GPA and advanced academic level have less problems in pronouncing silent letters.

Hago and Khan (2015) found out that Saudi learners tend to break up consonant clusters. The students of Hebron University's English department tend to insert an epenthetic vowel inconsonant clusters in $60 \%$ of the cases. The reason behind such error comes from the difference between the Arabic and English phonological systems. The Arabic phonetic system does not allow three-segment consonant clusters while Bauman-Waengler (2009) states that English has 14 four-segment clusters and 78 three-segment clusters that appear at the end of words, while Arabic has none. The students' attempt to harmonize their pronunciation with the requirements of their own language results in an incorrect sequence of English consonants.

The vowel errors were found to be the participants' largest pronunciation challenge. This result is in line with Bauman-Waengler (2009). BaumanWaengler concluded that English vowels are considered to be the greatest problem in articulation and perception for Arabic-speaking learners. The vowels errors occur because of two main reasons: the English vowel inconsistency and the effect of English orthography on pronunciation.

Arabic contains only six vowels: three long /a:, i: , u:/ and the other three are short /a, i, u/, while English (with some variation between British and American English) has 20 vowels: 6 long vowels, 6 short vowels and 8 diphthongs (Hassan, 2014). In this study, for example, $90 \%$ of the students did not pronounce the schwa correctly, since it does not exist in Arabic.

The Arabic spelling system is much simpler than that of English, for one reads what he/she sees and each letter symbolizes one sound whereas English vowel letters have variations. Arab students do not recognize that the English written vowels have variations. This explains why $95 \%$ of them pronounced 'tomb' as /tomb/ instead of /tu:m/.

\section{Conclusion}

English Students at Hebron University have common and systematic problems regarding the pronunciation of a number of English consonants and vowels. The errors committed by the students are in the sounds that are not familiar in the Arabic phonological system. Errors appeared mostly in the sounds: / $/ \mathrm{y} /, / \mathrm{p} /, / \mathrm{t} /, / \mathrm{l} /$, /3/and / $\mathrm{t} /$ / because they do not exist in the Arabic phonological system. The problem is that the students tend to replace these sounds with the nearest equivalents in their L1. They tend to replace the sounds mentioned above with the sounds from their language: $/ \mathrm{n}+\mathrm{g} /, / \mathrm{b} /, / \mathrm{l} /, / \mathrm{r} /, / \mathrm{d} /, / \mathrm{J} /$.

The most problematic sounds for the English students at Hebron University are the vowel sounds, the schwa in particular. This is due to what is called transfer (applying the rules and sounds of L1 in L2). The students tend to use the Arabic vowels /a/, /u/, /i/, /a:/, /u:/, /i:/ instead of the various English vowels. English orthography also affects the students' ability to produce the vowel variations. The disparity between the Arabic and English spelling systems causes the students to pronounce silent letters in some words. 
English students at Hebron University do not recognize that some vowels are diphthongs because they pronounce what is written and they are not familiar with the use of diphthongs in Arabic since the Arabic vowels are much simpler than the English vowels.

English Students at Hebron University have the tendency to break consonant clusters. Thiscan be attributed to the transfer between Arabic and English because the Arabic phonological system does not accept the sequence of three or more consonants.

Most of the English students at Hebron University believe that they can improve their pronunciation through looking up words in the dictionary, listening to the English sounds and words through using technology (audio aids), and the help of teachers who are native speakers of English. Students should have more phonetics and speaking courses. Also using the drilling technique helps train the speech organs to articulate the sounds that are exclusive to the English language.

\section{Limitations and Recommendations for Future Studies}

This study has a number of limitations. First, it is limited only to the students of the English Department of Hebron University including its three sections: English Literature, English Methods, and English Literature Minor French during the second semester of the academic year 2017/2018. Anotherlimitation includes the limited number of words used in the pronunciation test to record each studied item. It is recommended for future studies that researchers include at least five words to test the pronunciation of the /I/ vs. /e/ vowel. Future researchers could also discuss projects like including a sociolinguistic aspect by investigating whether males or females produce the same pronunciation errors.

Mohammed Farrah

Hebron University, Palestine

Email:mfarrah@hebron.edu

Nadia Halahlah

Hebron University, Palestine

Email: nadokhaledha@gmail.com 


\section{References}

Ababneh, Islam. (2018). 'English pronunciation errors made by Saudi students'. European Scientific Journal, ESJ, $14 \quad$ (2): 244261.http://dx.doi.org/10.19044/esj.2018.v14n2p244. (Retrieved on $15^{\text {th }}$ May 2018).

Alkhuli, Mohammad.(1983). English as a Foreign Language.Ph.D.Unpublished Dissertation, King Abdul Aziz Public Library.

Altaha, Fayez. (1995). 'Pronunciation errors made by Saudi university students learning English: Analysis and remedy'. International Review of Applied linguistics, $\quad 109, \quad 110-123$. https://doi.org/10.1075/itl.109110.05alt(Retrieved on $10^{\text {th }}$ Sep. 2017).

Amara, Mohammad. (2003).'Recent foreign language education policies in Palestine'. Language Problems \& Language Planning,27 (3): 217 231.https://doi.org/10.1075//plp.27.3.02ama(Retrieved on $15^{\text {th }}$ Nov. 2019).

Amara, Mohammad. (2018).'Palestinian schoolscapes in Israel'.Asian-Pacific Journal of Second and Foreign Language Education.3, 7 doi:https://doi.org/10.1186/s40862-018-0047-1(Retrieved on $15^{\text {th }}$ Nov. 2019).

Avery, Peter \& Ehrlich, Susan.(1992). Teaching American English pronunciation.Oxford: Oxford University Press.

Bauman-Waengler, Jacqueline. (2009). Introduction to phonetics and phonology. USA: Pearson Education.

Bianchi, Robert and Abdel Razeq, Anwar. (2017). 'The English language teaching situation in Palestine'.In Robert Kirkpatrick (ed.), English Language Education Policy in the Middle East and North Africa, 147169. Springer International Publishing.doihttps://doi.org/10.1007/978-3319-46778-8 10 . (Retrieved on $20^{\text {th }}$ Nov. 2019). 
Carter, Ronald. \&Nunan, David. (2001). The Cambridge Guide to Teaching English to Speakers of Other Languages. Cambridge: Cambridge University Press. http://dx.doi.org/10.1017/CBO9780511667206

Gilakjani, Abbas \&Ahmadi, Mohammad. (2011). 'A Study of factors affecting EFL learners' English listening comprehension and the Strategies for improvement'.Journal of Language Teaching and Research,2(5): 977988. doi:10.4304/jltr.2.5.977-988 (Retrieved on $15^{\text {th }}$ Oct. 2017).

Gimson, Alfred Charles \& Crutteden, Alan. (1994). Gimson's Pronunciation of English.London: Edward Arnold.

Hago, Omer Elshekh.,\& Khan, Waquar Ahmad. (2015). 'The pronunciation problems paced by Saudi EFL learners at secondary schools'.Education and linguistic research, 2, 25-99. DOI: https://doi.org/10.5296/elr.v1i2.7783 (Retrieved on $15^{\text {th }}$ Nov. 2017).

Hassan, Elkhair Muhammad Idriss. (2014). 'Pronunciation Problems: A case study of English Language students at Sudan University of Science and Technology'. English Language and Literature Studies; 4, No. 31 42.Doi:10.5539/ells.v4n4p31 (Retrieved on $15^{\text {th }}$ Oct. 2017).

Helm, Francesca, Guth, Sarah.\& Farrah, Mohammed. (2012). 'Promoting dialogue or hegemonic practice: Power issues in telecollaboration'. Language Learning \& Technology, $16 \quad$ (2), 103127.http://dx.doi.org/10125/44289(Retrieved on $15^{\text {th }}$ Sep. 2016).

Jabali, Oqab Mahmoud\&Abuzaid, Yousif Jamal. (2017). 'Pronunciation errors committed by Palestinian students at An-Najah National University: An Analytical Approach'. Arab World English Journal, 8 (2): 119-131.Doi:https://dx.doi.org/10.24093/awej/vol8no2.8(Retrieved on $10^{\text {th }}$ March 2018).

Kalaldeh, Raya.(2016). 'English Pronunciation Errors by Jordanian University Students'.Arab World English Journal, 7 (2). DOI: https://dx.doi.org/10.24093/awej/vol7no2.27 (Retrieved on $20^{\text {th }}$ Nov. 2018).

Kharma, Nayef., \& Hajjaj, Ali. (1989). Errors of English among Arabic speakers. Alfred place, London.

Levis, John. \&LeVelle, Kimberly. (2012). 'Social factors in pronunciation acquisition'. In. J. Levis \& K. Proceedings of the $3^{\text {rd Annual }}$ Pronunciation in Second Language Learning and Teaching Conference, Ames, IA: Iowa State University, 1-10. https://apling.engl.iastate.edu/wpcontent/uploads/sites/221/2016/06/Proceedings_3rd_PSLLT.pdf (Retrieved on $10^{\text {th }}$ Sep. 2017).

Munro, Murray J. (1998).'The effects of noise on the intelligibility of foreignaccented speech'.Studies in Second Language Acquisition, 20, 139154.Doi: 10.1017/S0272263198002022

Munro, Murray J 2003). 'A primer on accent discrimination in the Canadian 
context'. TESL Canada Journal, 20 (2): 38-51.

O'Connor, J. D. (1980). Better English Pronunciation (2nd ed.). Cambridge: Cambridge University Press.

Salah, Nidaa\& Farrah, Mohammed. (2012). 'Examining the use of Arabic in English classes at the primary stage in Hebron government schools, Palestine: Teachers' perspective.' Arab World English Journal AWEJ, 3 (2): $400-436$

Shamallakh, Mohammed. (2018). Investigating difficulties facing Palestinian EFL students in pronouncing English vowels. MA thesis published by the Deanship of Research and Graduate Studies. Islamic University, Gaza.https://www.mobt3ath.com/uplode/book/book-19383.pdf. (Retrieved on $15^{\text {th }}$ Sep. 2018).

Tushyeh, Hanna.(1996). 'Linguistic problems facing Arab learners of English. ITL: International Journal of Applied Linguistics. 111(1): 109117.https://doi.org/10.1075/itl.111-112.05tus. (Retrieved on $12^{\text {th }}$ Sep. 2016).

Yule, George. (1996). The Study of Language ( $2^{\text {nd }}$ ed.). Cambridge: Cambridge University Press.

Zuengler, Jane.(1988). 'Identity Makers and L2 Pronunciation'.Studies in Second Language, 10, 33- 49. 